UDC 323(460)

DOI: https://doi.org/10.18485/iipe_ria.2021.72.1181.4

Biblid 0543-3657, 72 (2021)

Vol. LXXII, No. 1181, pp. 55-73

Review article

\title{
IS SPAIN THREATENED BY A PERMANENT POLITICAL CRISIS?
}

\author{
Rajko PETROVIĆ ${ }^{1}$
}

\begin{abstract}
The political situation in Spain, after the failed attempt of a unilateral declaration of the independence of Catalonia, has become the subject of study by the scientific and professional public throughout Europe and the world. The strained political relations between official Madrid and Catalonia have reached their peak in the last few years, which leads us to the conclusion that the Spanish state is in a political crisis. In this paper, we will examine the potential sources of this crisis, which may include the crisis of the regional model of the state, the future of the monarchy, the crisis of Spanish identity, separatism in Catalonia and the Basque Country, the rise of the far-left and far-right, and other factors that may further induce political crisis (such as the economic and demographic situation). In conclusion, we will propose the improvement of the regional state as a solution (as opposed to the proposals on the federalization of Spain), as well as the abandonment of radical strategies wherever they come from.
\end{abstract}

Keywords: Spain; political crisis; the regional model of the state; Catalonia; the Basque Country; federalization.

\section{INTRODUCTION}

Today, the Spanish state is facing the biggest political challenges since the death of dictator Francisco Franco in 1975. Numerous problems burden the political life in Spain, which can result in a multidimensional political crisis. Accordingly, it is essential to identify and analyse these problems, so that an adequate solution can be proposed. If these problems were ignored (which has been a fairly common occurrence so far), Spain could face a crisis of unprecedented proportions, perhaps even a conflict outcome. The failed attempt to declare Catalonia's independence by separatist political forces in that Spanish region resonated most with the Spanish and European public, but it represents only part of the general political and economic discontent that has prevailed in

\footnotetext{
${ }^{1} \mathrm{PhD}$ student, Institute of European Studies. E-mail: rajkopetrovic993@gmail.com
} 
Spain in recent years. The political polarisation between the left and the right seems to have never been stronger since the crisis of the Second Republic, just like the general dissatisfaction of both sides. The terrorist separatist organisation $\mathrm{ETA}^{2}$, which has been fighting for decades to blackmail the independence of the Basque Country, has ceased to exist, but the Basque political forces have not given up on the project of an independent Basque state. Given the growing antagonism between the Castilian part of Spain, on the one hand, and a significant part of Catalonia, the Basque Country (and even Galicia), on the other, we believe that the Spanish national identity, which since its inception has served to create a sense of unity of all peoples in this part of the Iberian Peninsula, is seriously tested. The centuries-old polarisation between the supporters of monarchism and republicanism is very present today and additionally contributes to the general political division. On the other hand, Spain has been in an economic crisis for years, which adversely affects its political and demographic trends. The key to the functioning of Spain after the adoption of the Constitution of 1978 and the entry into the process of democratisation is its vertical organisation of government. The Constitution provides for the possibility of forming autonomous communities (or regions), which represent forms of political, economic, but also cultural and linguistic autonomy. Opinions on the Spanish Constitution are divided. Some consider it the guardian of the unity and indivisibility of the Spanish state and nation, some part of the problem, while some see in its reconstruction a solution to most of the political problems that burden the Spanish present. It is up to us to investigate structural problems of Spain such as the crisis of the regional model of the state in Spain, the crisis of the monarchy, the crisis of Spanish identity, the rise of the far-left and the farright, separatism in Catalonia and the Basque Country and others.

\section{THE CRISIS OF THE REGIONAL MODEL OF THE STATE}

The death of General Francisco Franco in 1975 also marked the end of an era in Spanish history. During his decades-long dictatorship, Spain was an undemocratic and one-minded society, which suppressed any form of pluralism and diversity with institutionalised coercion. From 1975 to 1986, Spain was in the process of democratic transition and consolidation. During that period, the Constitution of the Kingdom of Spain (1978) was adopted, which aimed to carry out the political and administrative decentralisation of the state, which was previously strictly centralised. At the very beginning of the fragile Spanish

\footnotetext{
${ }^{2}$ A Basque terrorist organisation that operated in the period between 1959 and 2018, advocating the secession of the Basque Country by force. It carried out dozens of attacks in which it killed over 820 people.
} 
democracy, the institutions of the army and the monarchy played a significant role in democratisation, and later the political parties gradually took over the primacy (Conversi 2002, 223). The 1978 Constitution established the Kingdom of Spain as a parliamentary monarchy. On the other hand, it also introduced a completely new form of vertical organisation of government. Although we will join the assessment that with this Constitution Spain has become a regional state, there are significant disputes in the theory of constitutional law on this issue. The question is whether Spain has become a decentralized unitary state or is it a de facto federation. However, the prevailing opinion is that Spain is a regional state, and the Spaniards themselves usually say that Spain is the so-called state of autonomy (Станковић 2012, 234-235). The Constitution, therefore, provides for the possibility of forming autonomous communities but does not provide for the exact number and scope of their competencies. That is why the Spanish model of regionalisation is rather asymmetric. A year after the adoption of the new Constitution, three regions with distinct historical, cultural and ethnolinguistic features were formed: Catalonia, Galicia and the Basque Country. Later, a total of seventeen regions was formed (Станковић 2012, 236).

There are many reasons why Spain is today organised as a regional state. Since its inception, Spain has been composed of different ethnic communities that have nurtured their language, tradition and culture, and have become attached to the areas they inhabit as one of the parts of their identities. Historically, there have often been misunderstandings between Castile (which aspired to centralism) and areas that wanted a greater degree of autonomy, and even independence (Perović 2010, 491). Precisely, because of that, Spain started the so-called "middle way" which meant giving a high degree of political, economic, cultural and linguistic autonomy to their regions, while those same regions were prevented from separating themselves from the Spanish state on their own initiative. This was to achieve the stability of the political system, as well as the unity and indivisibility of the state (Perović 2010, 498). Without going into too much detailed analysis of all the features of the regional model in Spain, we will pay attention to the building blocks of that model, which, after forty years of application, have become problematic. The Spanish model of regionalisation is asymmetric, which means that the regions do not enjoy the same degree of autonomy or competence. For example, the Basque Country and Navarre are regions that have a greater degree of autonomy than other Spanish regions (Станковић 2012, 237). This is certainly a problem for preserving the unity and indivisibility of Spain as a state of all Spaniards who, according to the Constitution, are equal (Constitucion Española 1978). When it comes to financing the system on which Spanish regionalisation is based, there is a problem related to the principle of solidarity between regions. Namely, it is a principle that implies achieving a financial balance between the regions so that richer regions will give 
more to the common state budget in order to help the development of poorer regions. This issue is particularly sensitive for Catalonia as the richest Spanish region (Станковић 2012, 246-247). The issue of tax collection is also a debatable part of this model of regionalisation. The Spanish Constitution provides for the exclusive competence of the state in the primary regulation of tax matters (Станковић 2012, 247). Given that taxes are the main source of income for each state (but also any unit of local self-government within it), tax autonomy is a key to economic and any other development. Part of the professional public in Spain considers the existing progressive system of taxation more than justified, believing that richer Spanish regions, just like other rich regions across the European Union, want more money for themselves without taking into account two facts. First, that their wealth is largely induced by the fact that they are part of the state of Spain, which, given its territory and population, is a significant market but also a partner for the European Union. Second, the rich Spanish regions themselves do not allow their rich provinces or municipalities to be exempted from financial equalisation within the region (Maqueda 2017). This, however, does not diminish the fact that rich Spanish regions are dissatisfied with the existing tax arrangement.

\section{THE CRISIS OF THE MONARCHY}

According to the Constitution, the king is the head of the State of Spain, a symbol of its unity and longevity, represents the state in international relations, and has an arbitrary role when it comes to the functioning of government institutions. He is obliged to perform all his functions in accordance with the Constitution and the laws (Constitucion Española 1978, 29321). Some of the most important functions of the Spanish king are sanctioning and promulgating laws, convening and dissolving the Assembly (Cortes Generales), calling elections in constitutional situations, calling referendums in constitutional situations, proposing and appointing candidates for Prime Minister, the supreme command of the armed forces, etc. (Constitucion Española 1978, 29322). Its role is much more symbolic and historical (traditional) in nature. As we can see, a good part of his functions is procedural, and it cannot be said that the real levers of political power are in his hands because the Government of Spain is, after all, the most important in the country. Despite the fact that today's monarch of Spain, Philip VI (Felipe VI), is only a pale shadow of the power of his ancestors, a significant part of society opposes not only the current monarch but also the monarchy as a whole. This is a significant factor that must be recognised and treated as one of the elements of a possible ongoing political crisis in Spain. Throughout history, there has been a strong polarisation in Spain between supporters of the monarchy and those who advocated a republican system. Republicans were nationally 
oriented, but they nurtured strong anti-monarchist and anti-clerical sentiments, considering them the obstacles to the development of democracy and society (Sanabria 2009). On the other hand, republicans still have tragic memories of the collapse of the Second Spanish Republic during the 1930s, as well as the decades-long Franco's dictatorship. Given that Franco appointed King Juan Carlos as his successor before his death, it is not surprising that many Spaniards see today's monarchy as a recurrence of a dark past. After King Juan Carlos voluntarily abdicated in favour of his son Philip in 2014, a huge anti-monarchist mood in Spain came to the surface. Many republicans saw it as an opportunity to protest in the streets against the monarchy and the royal family. Almost twothirds $(62 \%)$ of Spaniards believe that a referendum should be held on whether Spain should remain a monarchy or not. Research shows that, if such a referendum were held, $49 \%$ of Spanish citizens would support the monarchy headed by Philip, while $36 \%$ of citizens are ready to support the republican option. The then Spanish Prime Minister Mariano Rajoy rejected the possibility of holding such a referendum, believing that the citizens in a referendum on the new Constitution in 1978, among other things, confirmed that they wanted the monarch as the ceremonial head of state (The Guardian 2014).

Opinions about Spain as a monarchy are still deeply divided, and such a situation has and may have significant political consequences in the future. Spanish monarchists believe that the king is a symbol of Spanish unity, that he is an important representative of the state in the world, and that he is outside daily politics and in the service of exclusively national and state interests. According to them, the monarchy and the monarch are permanent categories, which do not change every couple of years, as is the case with the political parties in power, and form an important part of Spanish history, tradition and values. Republicans, on the other hand, see the monarchy only as a brake on the further political and economic development of Spain. Of course, they see the monarchy as one of the main culprits for the downfall of the First Spanish Republic ${ }^{3}$ and the Second Spanish Republic ${ }^{4}$, which further distances them from it. As convinced democrats, the proponents of the republic consider it trivial to talk about democracy and equality of all citizens when you have a royal family that lives privileged. At a time of economic crisis that is hitting Spain hard, the lavish behaviour of the Spanish royal family also raises the question of the economic justification for the existence of the monarchy (Govan 2014). Recent years of research show that as many as 7 out of 10 Spaniards under the age of 40 do not

\footnotetext{
${ }^{3}$ A short-lived republic that lasted from 1873 to 1874 , when the Bourbon dynasty was restored (King Alfonso XII came to the throne).

${ }^{4}$ The government in Spain in the period between 1931 and 1939, which consisted of a broad left-wing coalition. It was bloodily extinguished after the end of the Spanish Civil War.
} 
see a reason for the existence of the institution of the monarchy nor they understand the way it functions in today's society (Ramos Fernandez 2013, 209). Thus, former King Juan Carlos left Spain in August 2020 when he faced accusations of corruption and depositing money of suspicious origin in secret accounts in Switzerland in order to protect the reputation of the monarchy institution and make it easier for his successor (González 2020). All the previously presented data indicate that growing dissatisfaction with the institution of the monarch in Spain can be expected in the future, which may further contribute to the fragmentation of political life in this country.

\section{THE CRISIS OF SPANISH IDENTITY}

It is very important for the survival of a state that its citizens share a common identity, whether it is an old form of identity (religious, ethnic, linguistic) or a relatively modern civic identity. The Spanish identity ${ }^{5}$, that is, what should be the common identity of all those living in Spain, is quite endangered today, which can have far-reaching consequences. The Spanish Constitution of 1978 defined the recognition of linguistic, cultural and to some extent national pluralism in the country. This was a kind of compromise in order for the insufficiently integrated communities to accept, in addition to their authenticity, also the Spanish identity. It was up to the social and political elites to articulate that identity during the decades that followed. So, an identity that would be common for Castilians, Catalans, Basques, Gallegos, etc. The general assessment is that the support of citizens for the basic parameters of the 1978 constitutional compromise in this domain is still quite high (Martinez-Herrera and Jeffrey Miley 2010, 6). We are of the opinion, however, that the real situation on the ground is quite different. There is not even a single model of Spanish identity nurtured by all those who primarily feel like Spaniards, let alone those who feel exclusively like Catalans or Basques. The division over the notion of Spanish identity has

\footnotetext{
${ }^{5}$ National identity is a complex phenomenon that varies from identity belonging to a certain nation to belonging to a certain state. In the first case, it is about the ethno-national community, and in the second about the political one. The issue of Spanish identity is, given the ethnic, linguistic and cultural differences on Spanish soil, very complex. In this respect, Spain resembles other multinational and multicultural countries, such as the United Kingdom, Ukraine or Belgium. In these countries, the issue of identity is often blurred or divided between several different levels of identity (provincial, regional, state) and significantly affects the internal political dynamics of the country. The biggest problem such countries face is ethnically motivated separatism. Just as a significant part of Catalans or Basques want to separate from Spain, so do Scots in Great Britain, Flemings in Belgium and Russians in Ukraine. What is specific for the citizens of Spain is that they dominantly nurture the so-called dual identity, that is, they feel at the same time Spaniards and Andalusians or Spaniards and Valencians (Coller and Castelló 1999).
} 
lasted for decades. In the last two centuries, traditionalists and republicans have formed two mutually exclusive visions of Spanish identity, based on different symbols, myths and heroes. The traditional model of Spanish identity was formed in the Middle Ages. It is based on the myth of the Reconquista ${ }^{6}$ and the need to preserve the homogeneity of Spain as a country of the Christian religion and Latin culture. On the other hand, the republican (liberal) notion of Spanish identity developed at the beginning of the 19th century, at the time of Napoleon's invasion of Spain. The Spanish liberals realised that they had to develop their own democratic and progressive ideas in order to distance themselves from French influence. According to them, the authentic Spanish identity is not the one related to the Reconquista and the powerful Spanish Empire, but to the diversity in Spanish tradition and culture. Judging by that, tolerant Muslims from Andalusia, fighters for freedom and democracy from the Middle Ages onwards, etc., are also part of the Spanish identity (Torrecilla 2009).

Disagreements over the essential elements of Spanish identity are still present today. There is not even an essential agreement on what Spain is. Is it a state, a "nation of nations" or an ethno-patriotic entity? Also, there is no agreement on when the Spanish identity originated. Liberals believe that the modern Spanish nation was born out of resistance to the French occupiers in the 19th century. On the other hand, traditionalists view the Reconquista period as the birth of the Spanish nation as we know it today and see in its imperial expansion that followed the power of a united Spain (Torrecilla 2009, 206-211). On the other hand, Martin Ortega Carcelen has a far more flexible and inclusive view of Spanish identity today. According to him, it has three main dimensions: sharing global culture, sharing common principles and values of a modern democratic state, and participating in joint sharing at the global level. He perceives Spain as a specific political project, and the Spaniards as those who voluntarily agree to be a part of it (Ortega Carcelén 2016, 7). An example of disagreement over basic state symbols such as the flag and anthem are also symptomatic. According to the 1978 Constitution, the flag and anthem represent all Spaniards. The situation in practice, however, is a bit different. Today we have not only a multitude of Catalans or Basques who use their national flags, but also a part of the citizens from the rest of Spain who use the flags of the Second Republic (Díaz 2019). The anthem of Spain, as many people know, has no words, which speaks enough about the fact that there is no clear consensus between the two parts of Spain on Spanish history and Spanish identity (Pardo Torregrosa 2018). Despite the efforts of the constitution-makers to create a balance in the sense of identity that will be in the function of democratisation and stabilisation of Spain, the Spanish

\footnotetext{
${ }^{6}$ The name for the overall effort of Christians on the Iberian Peninsula to expel Muslim invaders, which lasted between 722 and 1492 .
} 
identity is not strong enough today in all parts of Spain. The vaguely defined identity of members of a community is a symptomatically favourable ground for the outbreak of political (or other) conflicts. Even decades after the collapse of Franco's dictatorship, there is no clear consensus on what Spain really is and what it means to be Spanish. It should be emphasised that the majority of citizens perceive themselves as Spaniards in the national sense and respect the existing state symbols and the anthem, so the views of authors like Torrecilla should be taken with a grain of salt. A survey conducted on this topic in 2017 showed that $42 \%$ of respondents are very proud of the fact that they are Spanish, but also that only $14 \%$ of respondents feel only Spanish, without a dual identity (Llaneras 2017). A survey on the same topic conducted two years earlier showed that 54.3\% of citizens consider themselves Spaniards and members of a certain region, of which only $15.7 \%$ are considered exclusively Spaniards (Statista 2015).

\section{THE RISE OF THE FAR-LEFT AND THE FAR-RIGHT}

The conflict between the left-wing and the right-wing in Spain was one of the most radical in Europe. ${ }^{7}$ Their uncompromising relationship reached its peak in the Spanish Civil War when the ruling left collapsed (Cveticanin 2015). The left-wing, however, has managed to survive in Spain to this day with its specific vision of this country. The Spanish left-wing has had its strong foothold in the Spanish people since the time of the Second Republic. Already the first free and democratic elections after the fall of the Francoist regime 8 in 1977 showed that leftist potential had not disappeared in decades of right-wing dictatorship. Out of almost 19 million voters in those elections, almost half gave their vote to political parties that advocated socialism. In these elections, the right-wing received a total of only $8.5 \%$ of the vote (which is not every tenth Spaniard)

\footnotetext{
${ }^{7}$ The conflict between the Spanish left and right has its roots in the 19th century. The political right in Spain dates back to the Carlist wars in the 19th century and conservative parties and movements that resisted the modernisation and liberalisation of the country. It made a strong influence during the reign of Miguel Primo de Rivera (1923-1930), culminating in the Franco era (1939-1975). All the time it was in direct political conflict with the Spanish left, regardless of whether it was the Socialist Workers' Party of Spain (founded in 1879), the Communist Party of Spain (founded in 1921) or anarchists and syndicalists of various kinds. The Spanish Civil War (1936-1939) was the culmination of political polarisation in Spain, where the conflict between the left and right coalitions resulted in several hundred thousand deaths and the establishment of a decades-long right-wing dictatorship that brutally persecuted leftists and their organisations.

${ }^{8}$ The dictatorship established after the end of the Spanish Civil War by General Francisco Franco, which was based on militarism, Spanish nationalism and ultra-Catholicism. The death of General Franco in 1975 is taken as the end of the dictatorship, that is, as the beginning of the Spanish "smooth" transition.
} 
(Inđić 1977, 373). Today, left-wing parties in Spain are a strong political force with huge potential. Since 2018, they have even become the ruling force in the country (Stanković 2018). The analysis of the trend of strengthening the political left is extremely important for the future of Spain, considering that, if certain ideas of the left are applied in practice, Spain, as we know it today, will not survive. From 2011 to 2018, Spain was ruled by a coalition gathered around the People's Party (Partido Popular, PP) led by the former Prime Minister of Spain Mariano Rajoy. This party is considered to belong to the right-centre of the political spectrum. The following data show how unstable the Spanish political scene is in the ideological sense. In the elections in 2015, the far-left party Podemos won as many as 69 seats (out of 350), while the People's Party experienced a significant drop-in support. The following year, Podemos, as the leader of other left-wing parties, experienced a significant decline, while the People's Party emerged from these elections as a convincing winner. Namely, the total percentage of votes won by left-wing parties dropped from $24 \%$ in the 2015 elections to $21 \%$ in the following year. It seemed to many at the time that the populist Podemos was only a short-lived political episode (Zarzalejos 2016, 184-185). However, it seems that such an assessment was premature, which is confirmed by Podemos participation in the current Spanish government. Namely, for the first time in modern history, Spain got a new prime minister by a vote of no confidence in Prime Minister Rajoy, and then elected the leader of the Party of Socialists (Partido Socialista Obrero Español - PSOE) Pedro Sanchez (Pedro Sánchez) as the new prime minister. Although his party had less than a quarter of the seats in parliament, Sanchez managed to gain the support of other leftists, primarily Podemos, but also Catalan and Basque nationalists, which upset the Spanish right-wingers (Нова срnска nолитичка мисао 2018). Podemos' support for the survival of the current government, formed after the November 2019 elections, is crucial because they represent a direct coalition partner of Sanchez's Socialists, where Podemos leader Pablo Iglesias became Second Deputy Prime Minister and Minister of Social Rights and 2030 Agenda. On the other hand, we believe that in the foreseeable future, this party could be the leader not only of the far-left part of Spain, but also of the Spanish state itself, thanks, among other things, to its charismatic and energetic leader Pablo Iglesias. Accordingly, it is important to analyse Podemos as an authentic Spanish left, which is de facto the fourth political force in the country, and which has quite radical ideas but also a position to put them into practice. Podemos is a far-left political party that was formed by gathering young university professors in early 2014. Already in May of the same year, the party won over 1.2 million votes (or 8\%) in the elections for the European Parliament, which was a big surprise. The leader of the party, Pablo Iglesias, announced that this was only the beginning of the fight for a fairer and more solidary Spain, free from Germany and the European Union. Only a month later, opinion polls 
showed that Podemos had the support of about $15 \%$ of voters. The growth of this party seriously threatened to shake up the traditional bipartisan in Spain, but also to introduce Spain into a time of general political and economic uncertainty (Torreblanca 2015, 10). As we previously pointed out, support for Podemos grew throughout 2015 until the 2016 elections, when it declined, though not drastically.

The ideas around which the people gathered in Podemos pose a threat to political stability in Spain. Given that we treat Podemos as a distinctly far-left party, in the analysis of the ideas of this party, we can find the causes of the sympathy of a large part of the voters towards it. First, since its founding, Podemos has strongly opposed the liberal model of democracy, considering it politically, economically, socially and environmentally unfair. Secondly, Podemos strongly opposes the European Union and its bureaucracy. They want the abolition of the Lisbon Treaty, as well as a change in the EU's economic relationship with Spain, which they consider to be exploitative. The supporters of the party are especially indignant at Germany and see it as the main culprit for the poverty of the southern EU states (we see left-wing internationalism through cooperation with, for example, Syriza from Greece). Third, the party initially advocated both Spain's exit from the NATO pact and the withdrawal of American troops from the country (Torreblanca 2015, 10-11). It is, therefore, a far-left political party that over a couple of years has become a threat not only to the dormant Spanish right, but also to the established Spanish left-wing parties (Ramiro and Gomez 2016, 109). This is a party that advocates the complete deconstruction of the model of the Spanish state as we know it today. The fact is that the leader of Podemos marked the Catalan independence referendum announced for 1 October 2017 as a legitimate act. Pablo Iglesias pointed out that, if his party wins power in the coming years, it will be ready for a significantly different arrangement between Spain and Catalonia, the Basque Country and Galicia (Garcia de Blas 2017). Such assessments often come from Podemos and can pose not only a threat to the existing model of a regional state but also to the territorial integrity of Spain.

It is no secret that Spain is still divided over the historical interpretation of the Spanish Civil War, as well as of Francoist Spain. Part of the Spanish conservative right-wing population still considers Franco one of the most important historical figures in Spain, while for leftists, he is a symbol of the suffering of the Spanish people (Minder 2015). As one of the first moves after coming to power, the new left-wing government ordered the removal of Franco's remains from the Valley of the Fallen mausoleum (which it did), believing that they reminded Spanish citizens of dictatorship and that the current purpose of the mausoleum did not honour and commemorate all Spaniards. This decision did not have as a reaction the stronger political mobilisation of the Spanish right, but it remains to be seen how the voters of the far-right Vox (who was in the 
Spanish parliament for the first time after the 2019 elections) will react. During its rule, the conservative People's Party opposed attempts to exhume Franco's remains, fearing that it would only awaken painful memories forty years after his death (PTC 2018b). The rise of the far-right Vox is especially significant. It is a party that was formed at the end of 2013. The legacy of Vox is the idea of Spanish nationalism, anti-separatism and Eurosceptic views. Vox opposes the immigration of migrants to Spain and fights against the "Islamization of Spain", especially by celebrating two periods in the history of that country - the Reconquista and the Francoism. On the other hand, Vox strongly opposes the political left at both the Spanish and global levels (Rubio-Pueyo 2020). Until 2018, Vox did not record significant results, and it seemed that it would pass like many nationalist parties and movements in that country during the transition period. However, at the end of that year, Vox won $10.97 \%$ of the votes in Andalusia, where it later participated in the formation of the government. A significant rise of the party at the national level followed. In the first general elections in 2019, Vox won 10.26\% (2.6 million votes), and a few months later in the new general elections, it won $15.09 \%$ (3.6 million votes). The political and economic crisis, especially in the conditions of the global coronavirus pandemic, will certainly affect the strengthening of such political parties.

\section{SEPARATISM IN CATALONIA AND THE BASQUE COUNTRY}

The biggest challenge the Spanish state faced in the last few decades was the strong separatist tendencies in its autonomous regions. In that sense, Catalonia and the Basque Country stand out as historical regions inhabited by people of special ethnic origin (in the case of the Basque Country), who speak languages other than Spanish (or Castilian), but also as regions that are one of the richest in Spain. In addition to the cultural-historical aspect, in these regions, there is an increasing emphasis on the economic aspect as one of the crucial drivers for gaining the independence of these regions (Payne 1971). Given that the history of political (and other) conflicts between Spain and these regions is too extensive, in this paper we will focus on the most current ones. As we know, Catalan nationalist political forces have been advocating for the secession of Catalonia from Spain for years. They justify it by the fact that throughout its history, Catalonia has always had its own political institutions of power, as well as cultural and linguistic specificity until Franco's dictatorship, when it was forcibly abolished. Today, more than forty years after the fall of the dictatorship, Catalonia is the richest Spanish region that enjoys a relatively high degree of autonomy within the Spanish state. After failed attempts to negotiate with the Spanish government to increase the scope of Catalonia's political, economic and cultural autonomy (the Spanish Constitutional Court in 2010 rejected most of the 2006 Catalan 
Statute proposals), Catalan nationalists led by their political elite decided to take more drastic steps. First, a symbolic referendum on independence was organised in 2014, in which the majority of voters voted in favour of Catalonia's independence, and then in 2015, the separatist parties won power in the regional elections. Carles Puigdemont became the president of the regional government of Catalonia, who already announced the holding of a referendum by which Catalonia will finally become independent from Spain. Despite the Spanish government's ban and the announcement that a possible referendum and an attempt at secession would be prevented by the state apparatus of force, the referendum on Catalonia's independence was held on 1 October 2017. Of the $43 \%$ of voters who turned out, $90 \%$ voted for the independence of this region, and the day of the referendum itself passed in great tension and clashes between the demonstrators and the Spanish police. Any attempt at a political solution to this crisis through dialogue between the central government of Madrid and the Catalan government has failed. As early as 27 October, Catalan MPs declared the independent Republic of Catalonia, while the Spanish government issued an arrest warrant for the Catalan politicians who organised the referendum. The Spanish government also used Article 155 of the Spanish Constitution and took direct control of the Catalan region. Carles Puigdemont fled to Belgium with some of his associates, while some were arrested and are currently in Spanish prisons for organising a revolt against the state (BBC News 2018). These events represented the biggest political crisis in modern Spain, which is currently under control, but its causes are not even close to being suppressed. One of the most famous terrorist organisations in modern Europe was ETA. It was a left-wing armed formation of Basque nationalists and fighters for the independence of the Basque Country, which emerged in 1959 as a reaction to Franco's repression of the Basque language, culture and national identity. During its existence, ETA has carried out hundreds of terrorist attacks throughout Spain, where a large number of civilians were killed (although the targets were often politicians and the armed forces), which were carried out in order to intimidate and extort the independence of the Basque Country. Even after the fall of the Francoist dictatorship, ETA did not agree to a peaceful democratic transition of the entire Spanish society. With this approach, ETA deeply divided the Basque society, and even those Basques who were in favour of independence from Spain. After 11 September 2001, ETA was faced with serious efforts of Spanish and French counterterrorism formations to eliminate it completely. The decline in the popularity of this terrorist group, the loss of its membership and the efforts of political and civic groups in the Basque Country to fight peacefully to achieve their goals, influenced ETA to stop terrorist activities in 2011 (Whitfield 2015, 1). ETA definitely announced the termination of its existence in 2018 . This gave Spanish citizens hope that tensions related to this Spanish region are a thing of 
the past. However, there are clear indications that the Spanish government in this region will now face a new kind of challenge. Shortly after the end of the ETA, the leader of the Basque separatists, Arnaldo Otegi, stated that, with dedicated work and daily activities, the political struggle for the independence of the Basque Country would continue. The fact that the militant ETA has been disbanded does not mean that Basque separatism as a strong political factor has disappeared (The Local 2018). For example, on the eve of the Catalan referendum on independence on 1 October 2017, tens of thousands of Basques took to the streets in support of the right of Catalans to declare whether they want to separate from Spain or not. It is no secret that the Basques hope for a similar referendum in their region in the future, given that close to $1 / 3$ of the Basque population wants the region to become an independent state. This was also stated by the spokesman of the Basque Nationalist Party, Joseba Egibar, during the recent Catalan crisis (Pereira 2017). The announcement of a new political crisis in the Basque Country could be the determination of Basque Prime Minister Iñigo Urkullu to put the Basque issue back on the agenda. Namely, in 2018, he met with about twenty ambassadors of European countries in Madrid and asked them for support in organising a referendum in the Basque Country regarding its future. He, like other members of the aforementioned Basque Nationalist Party, advocates an agreed referendum on the independence of the Basque Country from Spain (PTC 2018a).

\section{THE ECONOMIC AND DEMOGRAPHIC SITUATION IN SPAIN AS AN AGGRAVATING CIRCUMSTANCE}

The political situation in Spain could be further complicated in the coming period due to the unfavourable economic and demographic situation in it. That is why it is important to examine certain parameters of the Spanish economy and the demographic picture. After years of economic expansion, the Spanish economy began to show the first signs of exhaustion in 2006. With the outbreak of the global economic crisis in 2007 and its deepening over the next year, the Spanish economy is entering a cycle of economic decline. The crisis has affected the decline of the general standard of living of citizens, and economic issues have become one of the most important in the Spanish political discourse. Unemployment in Spain rose dramatically in the first years of the crisis, from $8.3 \%$ in 2007 to $20.1 \%$ in 2010 . The younger Spanish population (aged 16 to 25 ) was particularly affected by unemployment growth of as much as $41 \%$ (CarballoCruz 2011, 309-328). Only after a few years, the Spanish economy, through government austerity measures, began to record an average growth of $3.3 \%$ (period 2015-2017). The consequences of the initial impact of the crisis are very much being felt today, and the general impression is that the economy is slowly 
recovering. This is already causing strong political consequences in Spain, which may become even more dramatic over time. Today, Spain is the third EU country in terms of the inequality index of its population. About 10.2 million Spaniards live below the poverty line. The number of citizens who had to use the services of homeless care centres increased by 20.5\% between 2014 and 2016. In 2018, $37 \%$ of young Spaniards (under 25 ) were unemployed. The younger population employed in 2018 had 33\% lower annual incomes compared to their 2008 peers. The number of fixed-term contracts among young employees is growing (Michaine 2018). The economic crisis, which mostly affects the young Spanish population, induces a political crisis because it is the young population that is prone to political mobilisation. Economic dissatisfaction in Spain is closely linked to the demographic challenges facing this country. Many Spaniards leave their country and go to other EU countries in search of better jobs and living conditions. Official data show that since the outbreak of the great economic crisis in 2008, Spain has been entering deeper and deeper demographic problems. On average, over 350,000 Spaniards left their country annually between 2009 and 2018. Today, Spain, just like throughout its history, has a high rate of immigration, but it not only cannot fully compensate for the losses due to emigration but also influences the change in the demographic structure of the country. The state has suffered for years from negative natural growth and the growing share of the old population in the total population. The population over 65 in 2014 was 18.2\% of the total population. It is predicted that this percentage will increase to $24.9 \%$ in just fifteen years, and to an incredible $38.7 \%$ by 2064 (Instituto Nacional de Estadística 2014, 6-8). These are huge challenges for the Spanish economy, given that over the years, according to the given projections, it will lose more and more young and able-bodied population, and it will have to support more and more old population. This can lead to social unrest, which would only further complicate the general political situation in the country.

\section{CONCLUSION}

The Catalan crisis of October 2017 has been just one of the most visible and strongest manifestations of the political crisis that Spain as a country is facing. We believe that there are many factors that can lead the Spanish state into the years of permanent political crisis with an uncertain outcome. The regional model of the state, established after the collapse of the Francoist state, is today under attack by certain political factors. Not only do a significant part of the political representatives of the regions inhabited by special ethnic groups (Catalonia and the Basque Country) feel that the current model does not provide enough political, economic and cultural autonomy for their regions, but the rest of Spain often seeks federalization as a possible option. Such an option would meet 
resistance from a significant part of the citizens, especially those who believe that Spain needs more centralisation and not the other way around. Spain is formally a parliamentary monarchy, but the very institution of the monarch as head of state is increasingly being challenged. Despite the fact that the monarchy is seen as politically and economically unprofitable in the modern democratic world, Spain is still traditionally torn between republicans and monarchists, and that division is still an important part of the political discourse. The unique Spanish identity is increasingly being questioned. A good part of the citizens of Spain do not feel like Spaniards (a large part of the Basques, Catalans), and there are those who nurture a dual identity. The constitutional concept of Spanish identity as common to all citizens is undergoing increasing temptations today. Certainly, the lack of a unified civic and political identity in one community is a reservoir for political conflicts. The rise of the Spanish left-wing, which is in power today, and especially the Podemos party, may in the coming years lead to significant changes in Spain as we know it today. The Spanish left-wing mainly cultivates strong antiEU and anti-NATO sentiments, looking with suspicion at the liberal model of democracy that is still dominant in the world, and is traditionally republican and distinctly anti-monarchist. Of course, the most notorious political problems Spain is facing are Basque and Catalan separatism. Although the Basque terrorist and separatist organisation ETA has ceased to exist, the Basque political elite is increasingly committed to the peaceful and consensual separation of the Basque Country from Spain. Catalan political leaders in the regional parliament have intensified their efforts over the past few years to achieve the ultimate goal - the secession of Catalonia as an independent republic. The failed referendum from 2017 further deepened the Catalan crisis, and official Madrid and Barcelona are more distant than ever. Unfavourable economic and demographic trends in Spain can only contribute to the further polarisation of Spanish society and politics. In conclusion, Spain obviously needs a dialogue of all relevant political and social actors in search of a broad consensus on the future of this country. Without it, a lasting political crisis imposes itself as an inevitable state. We believe that neither side should insist on radical solutions because they can only be counterproductive. Giving a somewhat higher degree of autonomy to the Spanish regions than the existing one, without insisting on the federalization of Spain or unilateral secession of certain regions, seems to be the most optimal possible solution in the current circumstances. That would, at least in the foreseeable future, probably satisfy the appetites of the Catalan and Basque separatists. So, more than the existing regional state and less than the federal one. 


\section{REFERENCES}

BBC News. 2018. "Catalonia's bid for independence from Spain explained", January 31. https://www.bbc.com/news/world-europe-29478415

Carballo-Cruz, Francisco. 2011. "Causes and Consequences of the Spanish Economic Crisis: Why the Recovery is Taken so Long?” Panoeconomicus 3: 309328.

Coller, Xavier and Rafael Castelló. 1999. "Las bases sociales de la identidad dual: el caso valenciano.” Reis 88 (99): 155-183.

Conversi, Daniele. 2002. “The Smooth Transition: Spain's 1978 Constitution and the Nationalities Question". National Identities 4 (3): 223-244.

Constitucion Española. 1978. Boletin Official del Estado, Num. 311.1.

Cvetićanin, Neven. 2015. „Nema više ni levice ni desnice“, Politika, June 12. http://www.politika.rs/sr/clanak/330212/Nema-vise-ni-levice-ni-desnice

Garcia de Blas, Elsa. 2017. "Podemos: Catalan independence vote would be "legitimate mobilization", El País, May 26. https://elpais.com/elpais/ 2017/05/26/inenglish/1495798999_041436.html

González, Miguel. 2020. "Juan Carlos I abandona España para salvaguardar la Monarquía”, El País, August 4. https://elpais.com/espana/2020-08-03/el-juancarlos-i-comunica-a-su-hijo-su-decision-de-trasladarse-fuera-de-espana.html

Govan, Fiona. 2014. "Spain's royal family: the Spanish public's arguments for and against", The Telegraph, June 19. https:/ /www.telegraph.co.uk/news/worldnews/ europe/spain/10910996/Spains-royal-family-the-Spanish-publics-argumentsfor-and-against.html

Díaz, Diego. 2019. “Tenemos un problema con la bandera”, El Salto, November 8. https://www.elsaltodiario.com/politica/diego-diaz-tenemos-un-problema-conla-bandera

Inđić, Trivo. 1977. „Španija - druga godina postfrankizma”. Politička misao 3: 373-384.

Instituto Nacional de Estadística. 2014. "Population Projection for Spain, 20142064“, October 28. http://www.ine.es/en/prensa/np870_en.pdf

Llaneras, Kiko. 2017. “¿Cuántos nacionalistas españoles hay en España?”, El País, October 12. https://elpais.com/politica/2017/10/11/ratio/1507747264_ 973195.html

Maqueda, Antonio. 2017. "No, Catalonia is not being robbed", El País, September 25. https://elpais.com/elpais/2017/09/26/inenglish/1506410252_592782. html

Martinez-Herrera, Enric and Jeffrey Miley, Thomas. 2010. "The constitution and the politics of national identity in Spain". Nations and Nationalism 16 (1): 6-30. 
Michaine, Daniela. 2018. "Seven facts that show the dark reality of Spain's economic recovery", The Local, January 29. https:/ / www.thelocal.es/20180129/the-realityof-spains-economic-growth

Minder, Raphael. 2015. "Civil War Legacy Continues to Divide Spain’s Politics and Its Street", The New York Times, November 19.

https://www.nytimes.com/2015/11/20/world/europe/in-spain-civil-warlegacy-continues-to-divide-politics-and-streets.html

Нова српска политичка мисао. 2018. „Шпанија: Парламент изгласао неповерење Маријану Рахоју, нови премијер биће милер социјалиста ПеАро Санчес; Жан-КАод Јункер: Имам поверење у нову шпанску владу“, June 1.

http://www.nspm.rs/hronika/spanija-parlament-izglasao-nepoverenjemarijanu-rahoju-novi-premijer-bice-lider-socijalista-pedro-sances.html

Ortega Carcelén, Martín. 2016. Ser español en el siglo XXI. Madrid: Editorial Cuadernos del Laberinto.

Pardo Torregrosa, Iñaki. 2018. "Las letras del himno de España que nunca cuajaron", La Vanguardia, February 20. https://wwwlavanguardia.com/ politica/20180220/44916704670/historia-himno-espana-letras-olvidadas.html

Payne, Stanley. 1971. "Catalan and Basque Nationalism." Journal of Contemporary History 6 (1): 15-51.

Pereira, Nelson. 2017. "Basque separatists throw support behind Catalan referendum", euronews, September 29. http://www.euronews.com/2017/09/ 29/basque-separatists-throw-support-behind-catalan-referendum

Perović, Bojana. 2010. „Ustavno ustrojstvo regionalne države u Španiji“. Medunarodni problemi 62 (3): 489-530.

Ramiro, Luis and Raul Gomez. 2016. "Radical-Left Populism during the Great Recession: Podemos and Its Competition with the Established Radical Left". Political Studies 65: 108-126.

Ramos Fernandez, Fernando. 2013. "The monarchy, a journalistic taboo in Spain. The royal crisis and the circumstantial crisis". Revista Latina de Comunicacion Social 68 (9): 209-240.

PТС. 2018а. „Премијер Баскије тражи од ЕУ полршку за референдум.“ 22. јануар. http://www.rts.rs/page/stories/ci/story/2/svet/3011781/premijerbaskije-trazi-od-eu-podrsku-za-referendum.html

PTC. 2018b. „Санчез уклања Франкове посмртне остатке из маузолеја.“ 18. јун. http://www.rts.rs/page/magazine/sr/story/511/zanimljivosti/3174400/sance s-uklanja-frankove-posmrtne-ostatke-iz-mauzoleja.html

Rubio-Pueyo, Vicente. 2020. Vox: A New Far Right in Spain. New York: Rosa Luxemburg Stiftung. 
Sanabria, Enrique. 2009. Republicanism and Anticlerical Nationalism in Spain. New York: Palgrave MacMillan.

Станковић, Марко. 2012. „ОАлука Уставног суда Шпаније о уставности Статута Каталоније и њене последице“. Анали Правног факултета у Београду 60 (2): 234-255.

Stanković, Vladimir. 2018. „Otpisani” Sančez lako srušio Rahoja”, Večernje novosti, June 1. http://www.novosti.rs/vesti/planeta.299.html:730509-Otpisani-Sancezlako-srusio-Rahoja

Statista. 2015. "Sentimiento de identidad nacional vs. regional en España julio 2015." July 31. https://es.statista.com/estadisticas/480685/sentimiento-de-identidadnacional-vs-regional-en-espana/

The Guardian. 2014. "Majority in Spain want referendum on future of monarchy", June 8. https://www.theguardian.com/world/2014/jun/08/spain-majorityreferendum-monarchy

The Local. 2018. "ETA dissolved but Basque separatism remains strong", May 4. https:/ /www.thelocal.es/20180504/eta-dissolved-but-basque-separatismremains

Torreblanca, Jose Ignacio. 2015. "The Rise of Podemos". In: Aspen Review, edited by Aleksander Kaczorowski, Maciej Nowicki and Robert Schuster, 10-12. Prague: Aspen Institute.

Torrecilla, Jesus. 2009. "Spanish Identity: Nation, Myth and History." In: Identities on the Verge of a Nervous Breakdown, edited by Jesus Torrecilla, 204-226. Kansas: Studies in 20th and 21st Century Literature.

Whitfield, Theresa. 2015. The Basque Conflict and ETA: The Difficulties of an Ending. Washington: United States Institute of Peace.

Zarzalejos, Javier. 2016. "Populism in Spain: an analysis of Podemos". European View 15: 183-191. 


\section{PRETI LI ŠPANIJI TRAJNA POLITIČKA KRIZA?}

Apstrakt: Politička situacija u Španiji je, nakon neuspelog pokušaja jednostranog proglašenja nezavisnosti Katalonije, postala predmet proučavanja naučne i stručne javnosti širom Evrope i sveta. Zategnuti politički odnosi između zvaničnog Madrida i Katalonije su tokom poslednjih nekoliko godina dostigli svoj vrhunac, što nas navodi na zaključak da se španska država nalazi u političkoj krizi. U ovom radu ćemo ispitati potencijalne izvore te krize, u koje možemo uvrstiti krizu regionalnog modela države, pitanje budućnosti monarhije, krizu španskog identiteta, separatizam u Kataloniji i Baskiji, uspon krajnje levice i desnice, te druge činioce koji mogu dodatno indukovati političku krizu (poput ekonomske i demografske situacije). Zaključno s tim, predložićemo usavršavanje regionalne države kao rešenje (nasuprot predlozima o federalizaciji Španije), kao i odustajanje od radikalnih strategija ma odakle dolazile.

Ključne reči: Španija, politička kriza, regionalni model države, Katalonija, Baskija, federalizacija

received: 08.02.2021.

accepted: 22.03.2021. 